\title{
Seasonal march patterns of the summer rainy season in the Philippines and their long-term variability since the late twentieth century
}

\author{
${\text { Ikumi Akasaka }{ }^{1 *} \text { (D), Hisayuki Kubota }}^{2}$, Jun Matsumoto ${ }^{3,4}$, Esperanza O. Cayanan ${ }^{5}$, Rosalina G. de Guzman ${ }^{5}$ \\ and Flaviana D. Hilario ${ }^{5}$
}

\begin{abstract}
This study investigates the seasonal march patterns of rainfall in the Philippines from 1951 to 2012 and their long-term variability. In order to clarify the dominant patterns in the seasonal march of rainfall, an empirical orthogonal function (EOF) analysis was applied to pentad rainfall data of 30 stations. For the first EOF mode (EOF1), we obtained a pattern related to the summer rainy season. We then applied cluster analysis to the time coefficients of EOF1 in each year to classify the seasonal patterns of the summer rainy season. As a result, the patterns were classified into six clusters. We found a long-term change in the pattern appearances with three anomalous patterns frequently observed since the 1990s: (1) a pattern that has an indistinct dry season and a prolonged peak rainfall, (2) a pattern that has a distinct dry season and an earlier withdrawal of the summer rainy season, resulting in a shortened rainy season, and (3) a pattern with a distinct dry season as well as delayed onset and withdrawal of the summer rainy season. This study also shows the relations between these three patterns and the lower atmospheric circulation at the $850 \mathrm{hPa}$ level around the Philippines. Consequently, large positive and negative anomalies in geopotential height were observed around the Philippines for the distinct and indistinct dry seasons, respectively. The duration and condition of the dry season were greatly affected by the strength and location of the subtropical high especially for February-March. It is also noteworthy that the timing of the onset (withdrawal) of the summer rainy season is clearly related to that of the onset of the westerly (northerly) wind in the zonal (meridional) component around the Philippines. Further, the duration and amount of peak rainfall were directly influenced by the strength of the westerly winds in the zonal component. These three anomalous patterns tended to appear in the years when the warm or cold event of the El Niño-Southern Oscillation (ENSO) occurred. This study suggests that the long-term variability in the seasonal march of rainfall is considerably influenced by the variability in ENSO.
\end{abstract}

Keywords: Summer rainy season, Seasonal march, Philippines, Long-term variability, El Niño-Southern Oscillation

\section{Introduction}

The climate of the Philippines is characterized by a large volume and seasonality of rainfall (Coronas 1920; Flores and Balagot 1969). The seasonality of rainfall is more extreme than that of temperature and is influenced mainly by the Asian monsoon, tropical cyclones, and the orographic effect. Cayanan et al. (2011) argued that

\footnotetext{
* Correspondence: akasaka-i@isc.senshu-u.ac.jp

${ }^{1}$ Department of Geography, Senshu University, 2-1-1 Higashi-Mita, Tama-ku,

Kawasaki, Kanagawa 214-8580, Japan

Full list of author information is available at the end of the article
}

heavy rainfall in western Luzon is induced by both the location and the track of the tropical cyclones during June-September and the orographic effect. Kubota and Wang (2009) estimated that the tropical-cyclone-induced rainfall ratio from July to October exceeds $50 \%$ in northern Luzon. Moreover, the mean seasonal march of rainfall amount clearly differs between the western and eastern coastal regions of the Philippines because of the Asian monsoon and the orographic effect, as shown by station rainfall data reported by Akasaka et al. (2007) and by the satellite data by Chang et al. (2005). Both the 
rainfall amount and the seasonality of rainfall are important factors for the agriculture and economics of the Philippines. This is because the seasonal march of rainfall is characterized by not only the seasonal rainfall amount but also the onset, peak, withdrawal periods, and duration of the rainy season, which influence planting decisions and the timing of harvesting in the cultivation calendar. Therefore, whether the seasonal march of rainfall will change with future global warming is of great concern to the Philippines. To answer this question with a prognostic analysis, we must first investigate the past interannual and long-term variability in the seasonal march of rainfall and its causes.

Recent studies have explored interannual variability of the onset of the summer rainy season or the summer monsoon in or around the Philippines since the late twentieth century. Moron et al. (2009) used rainfall data collected at 76 stations between 1977 and 2004 and data from the Climate Prediction Center Merged Analysis of Precipitation (CMAP) from 1979 to 2005 to study the spatial and temporal variability of the onset of the summer monsoon and to assess the seasonal predictability of local onset dates. They identified important climatic factors that are essential for the prediction of the onset: the sea surface temperature (SST) over the tropical Pacific and Indian Oceans in March and the wind field at the $850 \mathrm{hPa}$ level in May. Akasaka (2010) studied the interannual variability of the onset of the summer rainy season throughout the Philippines using daily rainfall data collected at 39 stations between 1961 and 2000. The author pointed out that the onset was consistently delayed after the mid-1970s and that longterm changes in the onset might be related to the timing of the shift in the location of the western edge of the subtropical high over the Philippines. Kajikawa and Wang (2012) studied interdecadal changes in the South China Sea (SCS) summer monsoon onset for the period of 1979-2008. They pointed out that the relatively early onset of the SCS appeared during 1994-2008 and that the onset processes were closely connected to the northward seasonal march of the intertropical convergence zone, the enhanced intraseasonal variability, and the number of tropical cyclones over the western North Pacific (WNP) and SCS. However, the interannual variability in the seasonal march of rainfall, including not only the onset but also the withdrawal and duration of the rainy season, has been scarcely discussed in earlier studies. The purpose of this study is to elucidate the interannual variability in the seasonal march patterns of rainfall in the Philippines since the late twentieth century. This study also aims to reveal the relationship between interannual variations in the seasonal march of rainfall and the low-level atmospheric circulation around the Philippines.
In addition, it is well known that the seasonality of rainfall in the Philippines is largely affected by the El Niño-Southern Oscillation (ENSO) (Lyon et al. 2006; Lyon and Camargo 2009; Moron et al. 2009). For example, Ropelewski and Halpert (1987) showed that the El Niño brings about drier conditions around the Philippines between June and November. Using daily rainfall data collected at 35 stations between 1950 and 2010, Villafuerte et al. (2014) also indicated that significantly drier (wetter) conditions appear in the Philippines during the seasons of the El Niño (La Niña) close to the mature ENSO. Cruz et al. (2013) reported a decreasing trend in the southwest monsoon rainfall (June-September) in the Philippines between 1961 and 2010 and suggested a change in climate related to the long-term variability in ENSO. Moreover, Kubota et al. (2016) investigated the longer term variability in the Pacific-Japan (PJ) pattern and its relation to the climates of East Asia and the WNP summer monsoon from 1897 to 2013. They pointed out that the ENSO-PJ relationship had varied on interdecadal time scales and contributed to the interdecadal modulation of climate in the summer of the WNP. However, the variation of the seasonal march pattern of rainfall in relation to ENSO has rarely been studied. This study also discusses the relationship between the interannual and long-term variability in the seasonal march patterns of rainfall and ENSO.

The data and methodology used in this study are described in the next section. The dominant pattern in the spatial and temporal variability of rainfall and its classification are presented. Furthermore, we reveal the characteristics of each seasonal march pattern of the summer rainy season and its relationship with low-level atmospheric circulation. Finally, we discuss the relationship with ENSO and present a summary of the findings of this study.

\section{Methods/Experimental}

In this study, we used daily rainfall data between 1951 and 2012 provided by the Philippine Atmospheric, Geophysical and Astronomical Services Administration (PAGASA). Data collected at 35 stations, which included more than $80 \%$ of the daily data for the period of 1951 to 2012, were used. Missing rainfall data were not filled in. To investigate the seasonality of rainfall, excluding daily rainfall variations, pentad rainfall data were calculated when missing data of one pentad were less than 1 day.

Firstly, to detect dominant temporal and spatial patterns in the seasonal march of rainfall, an empirical orthogonal function (EOF) analysis was applied to the pentad rainfalls for 30 stations from 1951 to 2012, which had less than $5 \%$ missing values. Missing pentad rainfall data were replaced by the 62-year mean values. To 
consider the statistical distribution, pentad rainfall data were normalized by a cubic root and then standardized for the analysis. Second, to classify the seasonal march patterns of rainfall and reveal the interannual and long-term variability, cluster analysis, using the Euclidean distance and Ward's method, was applied to the time coefficients of the first two EOF modes. In this study, the cluster analysis was stopped at a point where the distances between the merged clusters increased remarkably (Wilks 2006). The characteristics of each EOF mode are described in further detail in the next section. Then, to show the characteristics of seasonality of rainfall exhibited by each cluster, composite analyses were applied to the pentad rainfall for the years classified in each cluster.

The $2.5^{\circ} \times 2.5^{\circ}$ grid data of wind fields and geopotential heights at the $850 \mathrm{hPa}$ level from the National Centers for Environmental Prediction/National Center for Atmospheric Research (NCEP/NCAR) reanalysis (Kalnay et al. 1996) from 1951 to 2012 were used. The pentad mean data of wind fields and geopotential heights were calculated using daily data in the same manner as that for rainfall data. To show the key areas and periods in the low-level atmospheric circulation related to the interannual variability in the seasonal march of rainfall, correlation and composite analyses were primarily used. The Oceanic Niño Index (ONI, http://origin.cpc.ncep.noaa.gov/products/analysis_ monitoring/ensostuff/ONI_v4.shtml), which is an index used to define ENSO periods shown by the Climate Prediction Center, National Oceanic and Atmospheric Administration (NOAA), was used to describe the relationship with ENSO. The ONI indicates the 3-month running mean of SST anomalies averaged in the Niño 3.4 region $\left(5^{\circ} \mathrm{N}-5^{\circ} \mathrm{S}\right.$ and $120^{\circ} \mathrm{W}-170^{\circ} \mathrm{W}$ ) calculated from the Extended Reconstructed Sea Surface Temperature (ERSST) version 4 (Huang et al. 2015). In this study, the ONI values for the period of October-December (OND) and January-March (JFM) were utilized because ENSO events that developed and continued for more than 1 year reached a mature phase during these periods (Tomita and Yasunari 1993).

\section{Results and discussion}

Temporal and spatial variability of the seasonal march of rainfall

The result of the EOF analysis of pentad rainfall for the period of 1951-2012 showed two dominant EOF modes, as was the case discussed by Akasaka (2010) who applied the EOF analysis of pentad rainfall to data from 39 stations in the Philippines from 1961 to 2000. The combined contribution of the first and second EOF modes (EOF1 and EOF2) was more than 50\% since EOF1 and EOF2 accounted for 34.6 and $16.9 \%$ of the total variance, respectively.

The spatial pattern of EOF1 indicated a positive sign throughout the Philippines, and high loadings appeared, especially in the western part, at around $10^{\circ} \mathrm{N}-16^{\circ} \mathrm{N}$ (Fig. 1a). The mean time coefficient of EOF1 averaged for the period between 1951 and 2012 changed sign around the 29th pentad (late May) and the 71st pentad (mid-December), as shown by the red and blue inverse triangles in Fig. 1b. These results indicate that the summer rainy season starts simultaneously in the entire Philippines around late May and withdraws toward midDecember. These characteristics appear particularly in the western part around $10^{\circ} \mathrm{N}-16^{\circ} \mathrm{N}$, where the windward side of the southwest monsoon is located. Lower factor loadings of less than 0.5 appeared in the southeastern part of the Philippines, corresponding to the area where it has the rainfall peak for November-January by the northeast monsoon and the orographic effect as shown by Akasaka et al. (2007). That is, EOF1 mainly shows consecutive rainfall variations from late May to mid-December, which are characterized by the onset and withdrawal of the southwest monsoon.

On the other hand, the spatial pattern of EOF2 showed a different signal between the northwestern part of Luzon Island and the eastern part of the Visayas and Mindanao (Fig. 1c). The mean time coefficients of EOF2 changed sign around the 20th pentad (early April) and the 57th pentad (early October) and showed the peak of the positive and negative signs around the 44th-46th pentads (early and mid-August) and from the 65th pentad (mid-November) to the 2nd pentad (early January), respectively (Fig. 1d). These characteristics correspond to regional differences in the period of the peak rainfall. As shown by Akasaka et al. (2007), this is because the peak rainfall in the northwestern part is mainly influenced by the southwest monsoon along with the development of the monsoon trough and because the peak rainfall in the southeastern part is mainly influenced by the northeast monsoon and the easterly wind brought from the subtropical high. In this study, as discussed in the next section, we focus on the interannual variability in the seasonal patterns related to the summer rainy season across the entire Philippines as shown by EOF1.

\section{Seasonal march patterns of the summer rainy season and its long-term variability}

To clarify the interannual variability in the seasonal march of rainfall, cluster analysis was applied to the time coefficients of the first two EOF modes. The seasonal march of the summer rainy season stemming from EOF1 showed remarkably distinct differences between each cluster and the long-term changes. Therefore, the characteristics of the patterns of the time coefficients of EOF1 were the primary focus of this study. Figure 2 shows the dendrogram of the cluster analysis for the time coefficients of EOF1 and the corresponding plot of the distance between merged clusters in the cluster 

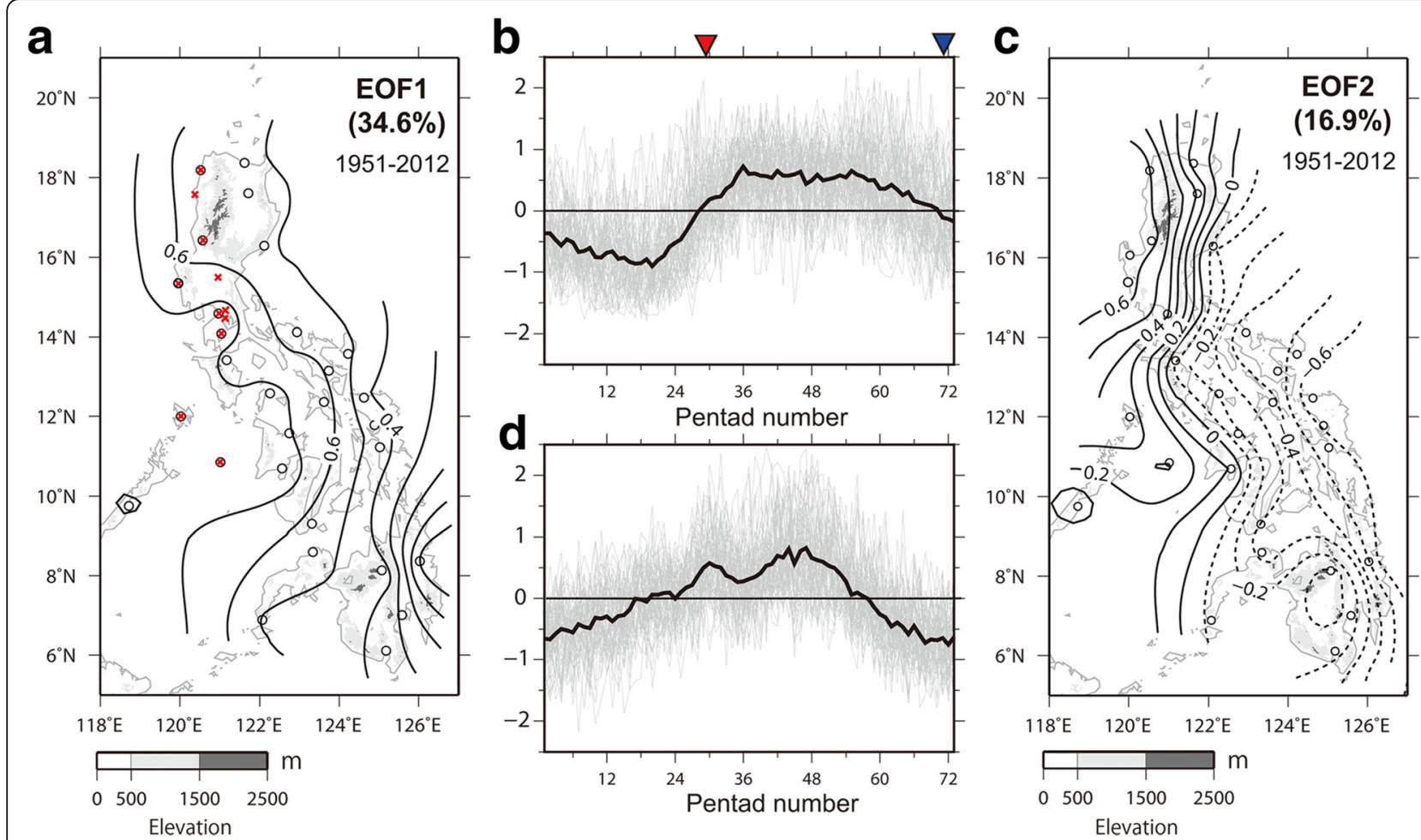

Fig. 1 Factor loadings and the time coefficients of EOF1 and EOF2. The contour interval is 0.1 in $\mathbf{a}$ and $\mathbf{c}$. The open circles in $\mathbf{a}$ and $\mathbf{c}$ indicate the observation stations used for the EOF analysis. The red cross marks in a indicate the observation stations used in Fig. 4. The thick and thin lines in b and $\mathbf{d}$ indicate the mean time coefficients averaged for 1951-2012 and the time coefficients in each year, respectively. The red and blue inverse triangles in $\mathbf{b}$ denote the first pentad (the 29th and 71st pentads) when the sign of the mean time coefficients for the EOF1 changed

analysis. We stopped the process in the cluster analysis before the 58th stage because the distance between the merged clusters showed discontinuity after that stage. On the basis of these results, we classified the patterns in the time coefficients of the EOF1 for the period of 1951-2012 into six clusters (Table 1).

The mean time coefficients of EOF1 for each cluster are shown in Fig. 3. In addition, the mean seasonal marches of rainfall in the western coastal region for each cluster are shown in Fig. 4. The observation stations, used in Fig. 4 and shown as red cross marks in Fig. 1a, correspond to those with high loadings in the spatial pattern of EOF1 and those where the windward side of the southwest monsoon is located. Therefore, the seasonal march of the summer rainy season for this area shows more sharp differences in each cluster.

The averaged time coefficients of cluster 1 (C1) displayed a normal pattern similar to that for the averaged 62 years, as denoted by the dotted line in Fig. 3. In the seasonal march of rainfall pattern of $\mathrm{C} 1$ (Fig. 4a), the onset of the summer rainy season, indicated by a red inverse triangle, started around the 27th pentad (midMay), with the peak rainfall appearing between the 44th and 46th pentads (early and mid-August). The summer rainy season gradually began to withdraw from the northern to southern parts of the region toward the 69th pentad (early December). Note that the region north of $16^{\circ} \mathrm{N}$ only had one peak rainfall amount, and the seasonal march of the rainy season for any other cluster did not display such characteristics.

The mean time coefficients for cluster 2 (C2) changed sign dramatically around the 26th pentad (early May; Fig. 3b). This corresponds to the abrupt increase in rainfall amounts around early May when the rainy season begins earlier than average (Fig. 4b). Furthermore, the peaks in rainfall appeared intermittently to the north of $14^{\circ} \mathrm{N}$ around mid-May, late June, and late August. The mean time coefficients changed sign from positive to negative at almost the same time compared with the 62-year mean.

In the mean time coefficients for cluster 3 (C3), the change from negative to positive occurred almost simultaneously with the 62-year mean (Fig. 3c). The positive value started to become negative around the 60th pentad (late October), earlier than the average for 62 years. As shown in Fig. 4c, this corresponds to a pattern of earlier withdrawal of the summer rainy season around late October.

Cluster 4 (C4) shows an anomalous pattern in which the mean time coefficients largely vary from the 3rd pentad (mid-January) to the 24th pentad (late April) 


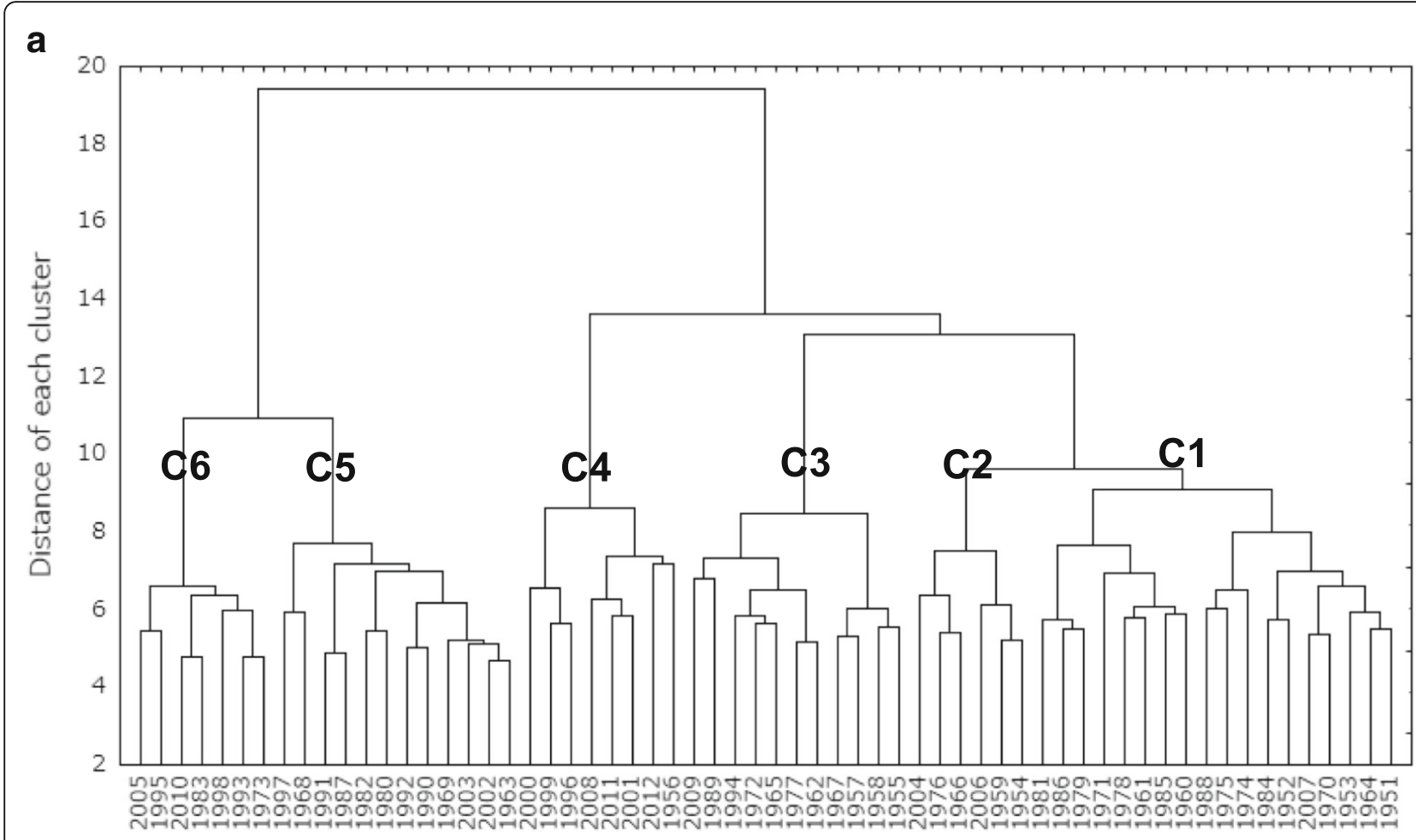

b

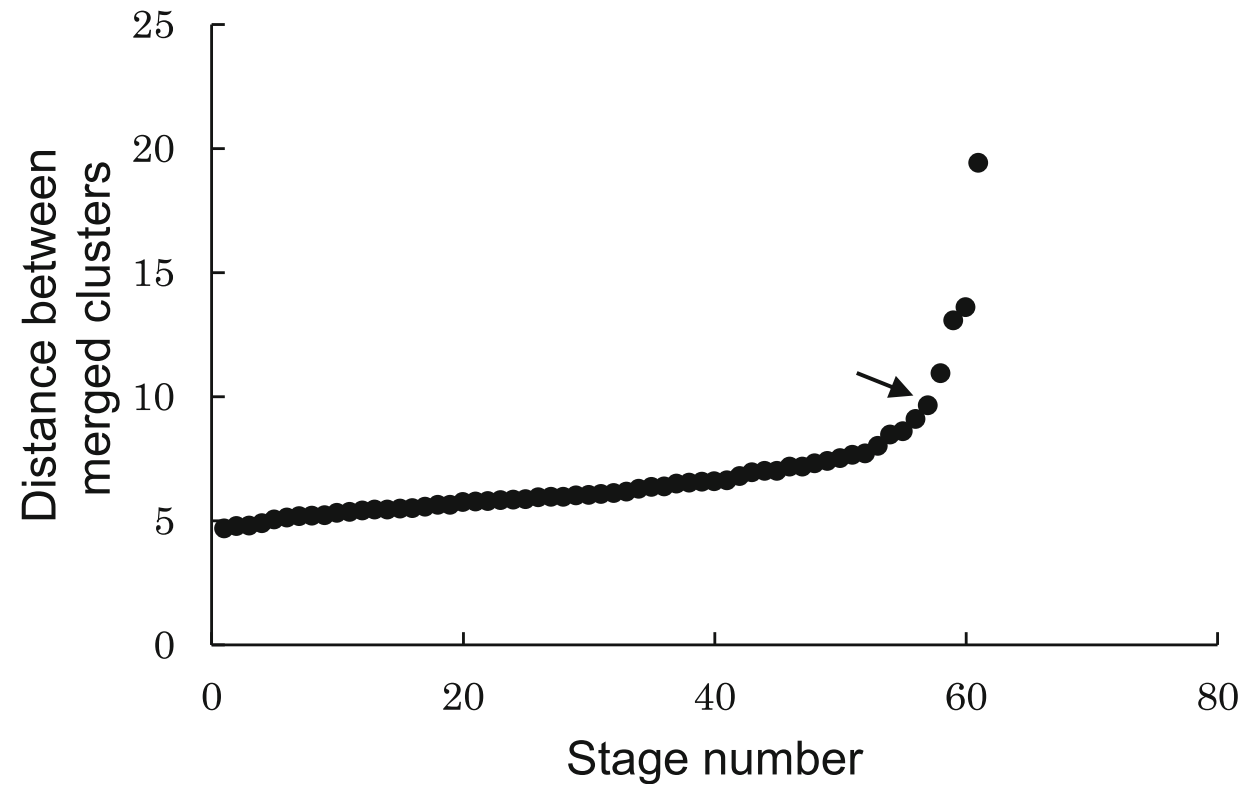

Fig. 2 Dendrogram of cluster analysis to the time coefficients of EOF1 (a) and the corresponding plot of the distance between the merged clusters (b). The arrow in $\mathbf{b}$ indicates the stage number just before distances between the merged clusters become large in the process of cluster analysis

toward the positive phase, higher than the 62-year mean time coefficients (Fig. 3d). Such variations were not shown in the mean time coefficients for any other clusters for the period. This indicates that there exists an indistinct dry season between January and April as compared to the 62-year mean (Fig. 4d). The summer rainy season started around the 24th pentad (late April), earlier than the 62-year mean, and withdrew toward the end of the year. Moreover, in Fig. 4d, it is also noteworthy that the period of the peak rainfall was 
Table 1 Patterns classification in the time coefficients of EOF1 for 1951-2012 based on cluster analysis

\begin{tabular}{ll}
\hline $\begin{array}{l}\text { Patterns in the time } \\
\text { coefficients of EOF1 }\end{array}$ & Years \\
\hline C1 & $1951,1952,1953,1960,1961,1964,1970,1971$, \\
& $1974,1975,1978,1979,1981,1984,1985,1986$, \\
& 1988,2007 \\
C2 & $1954,1959,1966,1976,2004,2006$ \\
C3 & $1955,1957,1958,1962,1965,1967,1972,1977$, \\
& $1989,1994,2009$ \\
C4 & $1956,1996,1999,2000,2001,2008,2011,2012$ \\
C5 & $1963,1968,1969,1980,1982,1987,1990,1991$, \\
& $1992,1997,2002,2003$ \\
C6 & $1973,1983,1993,1995,1998,2005,2010$ \\
\hline
\end{tabular}

significantly prolonged, with large rainfall periods from the 36th to the 54th pentads (late June to late September) to the north of $14.5^{\circ} \mathrm{N}$ compared with any other clusters.

In the mean time coefficients for cluster 5 (C5), a change into a negative sign occurred around the 67th pentad (late November), earlier than the 62-year mean time coefficients (Fig. 3e). The mean time coefficients for $\mathrm{C} 5$ fell remarkably below those averaged for 62 years from the 9th pentad to the 26th pentad (early February to early May). These correspond to an earlier withdrawal and a subsequent distinct dry season (Fig. 4e). The summer rainy season started at almost the same time as the 62 -year mean. Additionally, the clear double peaks in the rainfall amounts during the 40th-52nd pentads (mid-July to mid-September) are shown to the north of $14.5^{\circ} \mathrm{N}$.

The mean time coefficients for cluster 6 (C6) fell toward the negative from the 1st pentad (early January) and continued to be significantly below zero until the 30th pentad (late May; Fig. 3f). That is, both C5 and C6 denote a distinct dry season before the monsoon onset. Additionally, the change in the sign from negative (positive) to positive (negative) is delayed compared to the 62-year average (Fig. 3f). The changes indicate that an increase (decrease) in the amount of rainfall associated with the onset (withdrawal) of the summer rainy season tended to be delayed (Fig. 4f). Moreover, peak rainfall was not clearly shown to the north of $15.5^{\circ} \mathrm{N}$.

Figure $5 \mathrm{a}$ reveals the notable long-term variability in the seasonal march pattern of the summer rainy season. Before 1990, C1 and C3 were frequently observed, and C4 and C6 appeared only rarely in 1956, 1973, and 1983 before 1990. In particular, C1 was a normal pattern for the seasonal march of the summer rainy season prior to 1990. However, C1 appeared only in 2007 after 1990. Thus, the dominant patterns, which appeared more frequently, have changed from $\mathrm{C} 1$ and $\mathrm{C} 3$ to $\mathrm{C} 4, \mathrm{C} 5$, and C6 since the early 1990s. It is noteworthy that C4 and C6 have appeared frequently since 1996 and 1993, respectively, whereas $\mathrm{C} 5$ has sometimes been observed before the early 1990s. This means that an anomalous pattern, which has an indistinct dry season and a prolonged peak rainfall shown by $\mathrm{C} 4$, has appeared frequently since the late 1990s. The opposite pattern, with a distinct dry season notably shown by $\mathrm{C} 5$ and $\mathrm{C} 6$, has also been frequently observed since the early 1990s. In particular, C6 showed an anomalous pattern, characterized by both delayed onset and withdrawal of the rainy season, and has frequently appeared since the early 1990s. That is, the seasonal march pattern in the summer rainy and dry seasons has changed since the early 1990s.

\section{Characteristics of the low-level atmospheric circulation related to the seasonal march of the summer rainy season}

To clarify the relationship between the seasonal march of the summer rainy season and the low-level atmospheric circulation fields, the correlation maps between the time coefficients of EOF1 and the geopotential heights and wind fields at the $850 \mathrm{hPa}$ level are shown for the period between 1951 and 2012 in Fig. 6. The area with a significant negative correlation in the geopotential height widely spreads from India to the Philippines, especially around the center of the SCS and the Philippines (Fig. 6a). Similarly, but slightly to the south, the area with a significant positive correlation in the zonal component of the wind field was broadly distributed from around the south of India to the south of the Philippines (Fig. 6b). In the meridional component of the wind field, significant positive correlations were dispersed around the Bay of Bengal and from the southern part of the SCS to the northeastern part of the Philippines (figure not shown). This suggests that the interannual variations in the time coefficients of EOF1 were closely related to those in South and Southeast Asian summer monsoons because the areas with a significant correlation of the same sign widely spread from around India to the Philippines. This was especially true for the geopotential height and the zonal component of the wind field: the lower (higher) geopotential height and the strengthened (weakened) westerly winds around South and Southeast Asia not only led to an increase (decrease) in the amount of rainfall but also changed the seasonal march of the summer rainy season throughout the Philippines.

Next, in order to discuss the variability in the geopotential heights and wind fields related to the anomalous patterns in the seasonal march of the summer rainy season, time-latitude cross sections of the lower atmospheric circulation averaged between $120^{\circ} \mathrm{E}$ and $125^{\circ} \mathrm{E}$ are shown for C4, C5, and C6 in Figs. 7, 8, and 9. This longitudinal zone, including the Philippines, corresponds to that where higher correlations were revealed in the correlation maps shown in Fig. 6. In particular, the seasonality of the lower 


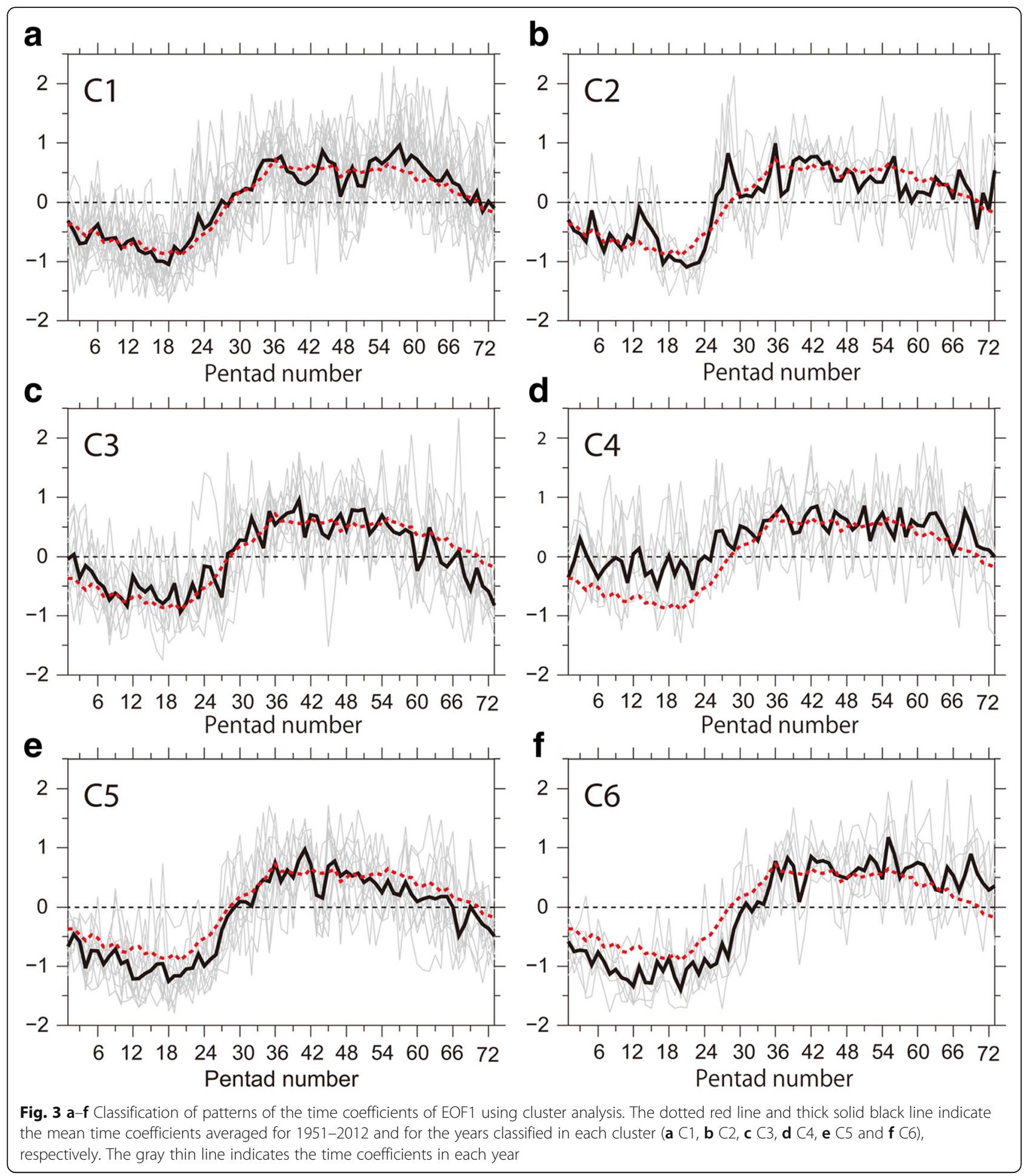

atmospheric circulation years classified in C4, C5, and C6 was compared to that classified in $\mathrm{C} 1$, which was the normal pattern prior to 1990 . The latitudinal cross sections for $\mathrm{C} 1$ are shown in Fig. 7a, d, g.

In the years classified in $\mathrm{C} 4$, the geopotential heights were significantly lower around $15^{\circ} \mathrm{S}-15^{\circ} \mathrm{N}$ from the first to the 18th pentad (January-March; Fig. 7b, c). The easterly and northerly winds were significantly weakened between the equator and $15^{\circ} \mathrm{N}$ for this period compared to $\mathrm{C} 1$ (Fig. 7e, $\mathrm{f}$ and $\mathrm{h}, \mathrm{i}$ ). The wind direction of the zonal (meridional) component started to change into a westerly (southerly) wind between the equator and 


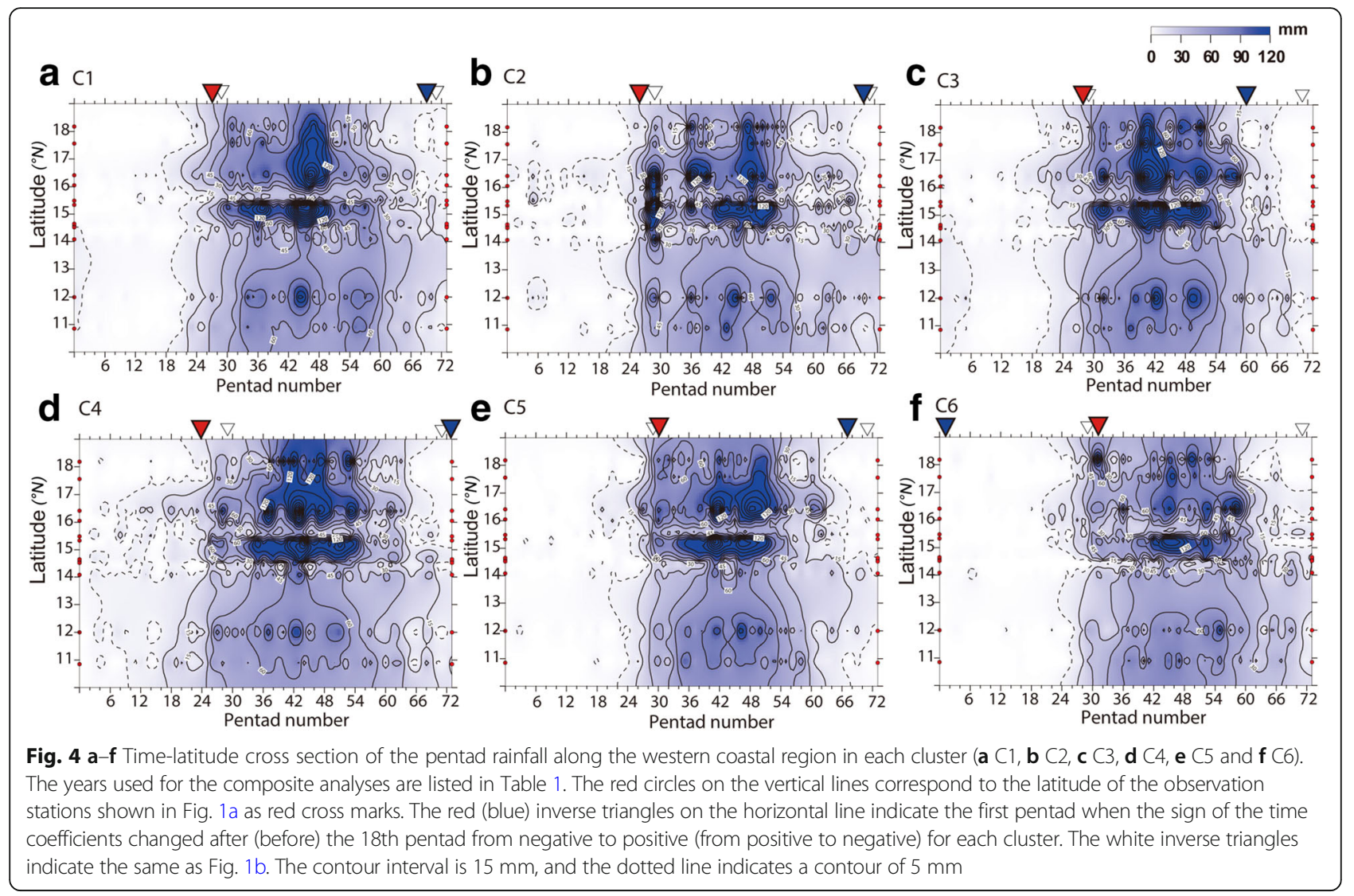

$20^{\circ} \mathrm{N}$ around the 26th pentad (early May), although the onset of the southwesterly wind is in mid-May on average, as shown by Akasaka et al. (2007) and Moron et al. (2009). These characteristics in the lower atmospheric circulation anomalies correspond to the weakened subtropical high from January to March and the earlier onset of the southwesterly wind. Thus, it is suggested that these lead to an indistinct dry season during January-March and an earlier onset of the rainy season in the years classified in C4. Additionally, strong westerly winds were seen around $15^{\circ} \mathrm{N}$ not only for the 41st-44th pentads (late July to early August) but also for the 48th-54th pentads (late August to late September; Fig. 7e, f); the period for strong westerly winds is longer than $\mathrm{C} 1$ (Fig. 7d). This corresponds to the prolonged peak rainfall with a large rainfall as shown in Fig. 4d.

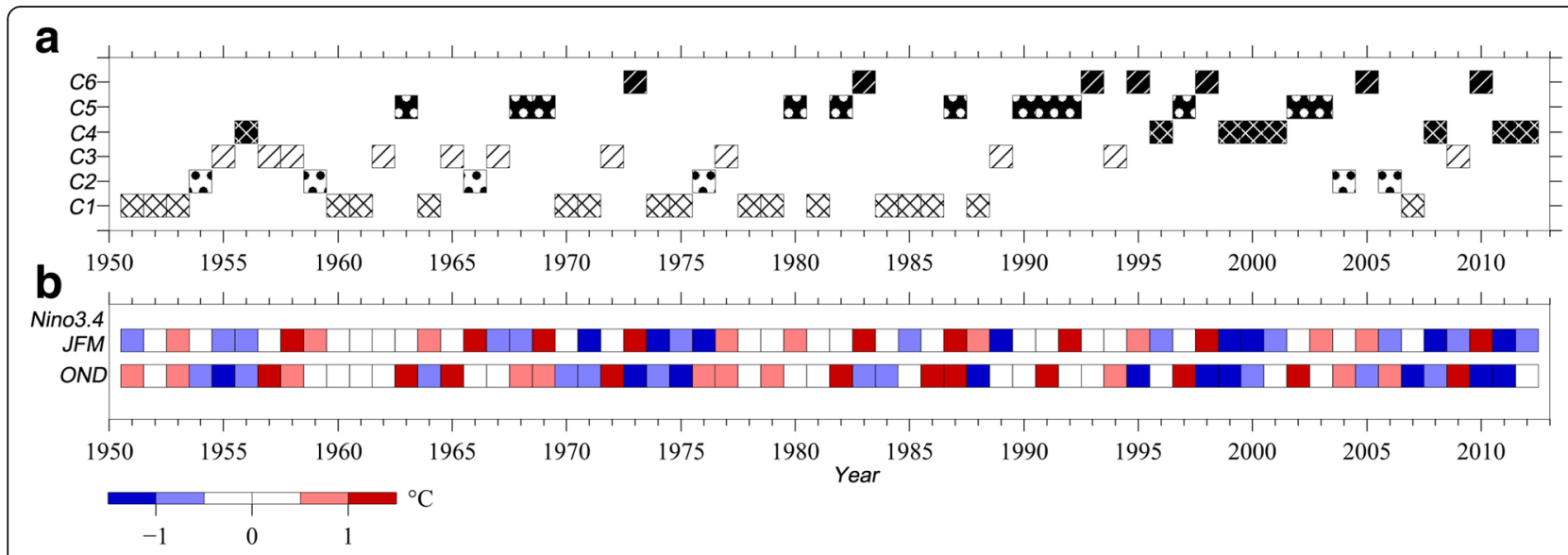

Fig. 5 Long-term variability in the seasonal march pattern of the summer rainy season. a A diagram of each cluster for the period of $1951-2012$. b ONI (the 3-month mean SST anomalies averaged in Niño 3.4) for January-March (JFM) and for October-December (OND) 


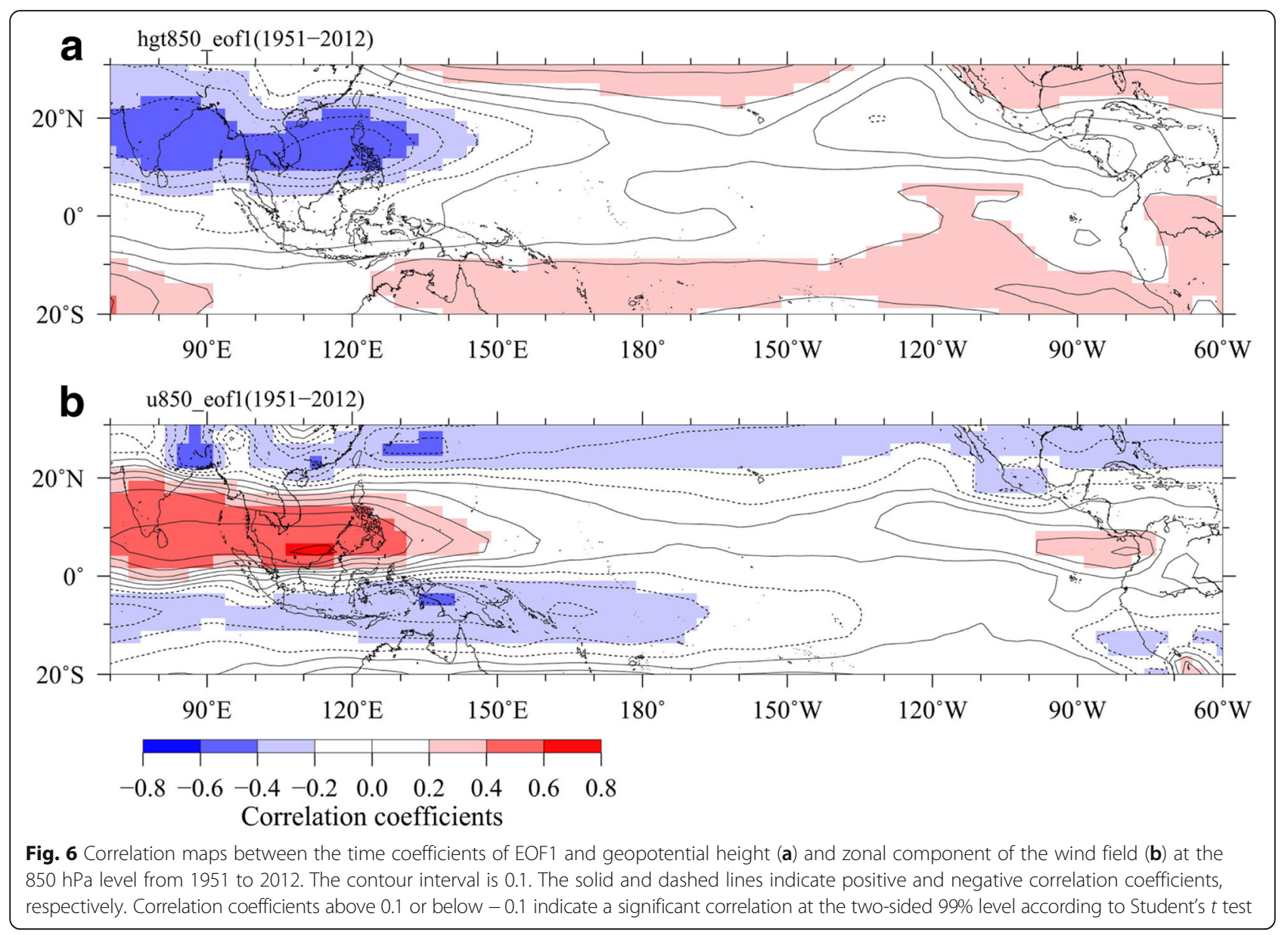

In the years classified in $\mathrm{C} 5$, it is noteworthy that the broad and continuous significant positive geopotential height anomalies, indicating a strengthened subtropical high, were observed from $10^{\circ} \mathrm{S}$ to $25^{\circ} \mathrm{N}$ especially for the 10th-12th pentads (mid-February to the beginning of March) and the 52nd-56th pentads (mid-September to early October; Fig. 8a, b). It has been suggested that the subtropical high is stronger and the convective activity is suppressed around the Philippines, especially for these periods. The westerly winds started to blow throughout the Philippines around the 32nd pentad (early June; Fig. 8c), although the onset of the westerly wind was the 30th pentad (late May) in C1 (Fig. 7d). For the 40th-42nd pentads and the 48th-52nd pentads (mid-July to late July and late August to midSeptember), the westerly wind strongly blew from $5^{\circ} \mathrm{N}$ to $20^{\circ} \mathrm{N}$ (Fig. 8c, d). This indicates that peak rainfall clearly appears during this period, as shown in Fig. 4e. Additionally, it is noteworthy that the northerly wind of the meridional component started to blow around the northern part of the Philippines from the 50th pentad (early September), which is earlier than C1 (Fig. 8e, f). The northerly wind then progressed toward the south until the 54th pentad (late September). Significantly high geopotential height anomalies were also shown around $20^{\circ} \mathrm{S}-20^{\circ} \mathrm{N}$ after the 52nd pentad (mid-September; Fig. 8b). As a result, C5 indicates an earlier withdrawal of the summer rainy season and a distinct dry season.

In the years classified in $\mathrm{C6}$, the higher geopotential height was located around $15^{\circ} \mathrm{N}-20^{\circ} \mathrm{N}$, which corresponds to the latitude of the Luzon Island, around the 1st-28th pentads (January to mid-May; Fig. 9a). The significant positive anomalies of the geopotential heights appeared between $20^{\circ} \mathrm{S}$ and $20^{\circ} \mathrm{N}$, especially from the 7th-10th pentads (early and mid-February; Fig. 9b). C5 also showed similar characteristics (Fig. 8b). This means that both $\mathrm{C} 5$ and $\mathrm{C} 6$ have the distinct dry season before the monsoon onset (Fig. 4e, f). The distinct dry season shown in C5 and C6 is closely related to the strengthened subtropical high around the Philippines, especially for February-March (Additional file 1: Figure S11). In the wind fields, it is noteworthy that the easterly wind continued around the Philippines until the 40th pentad (mid-July), and subsequently a weak westerly wind started to blow (Fig. 9c). The negative anomalies of the zonal wind were significantly and continuously shown 


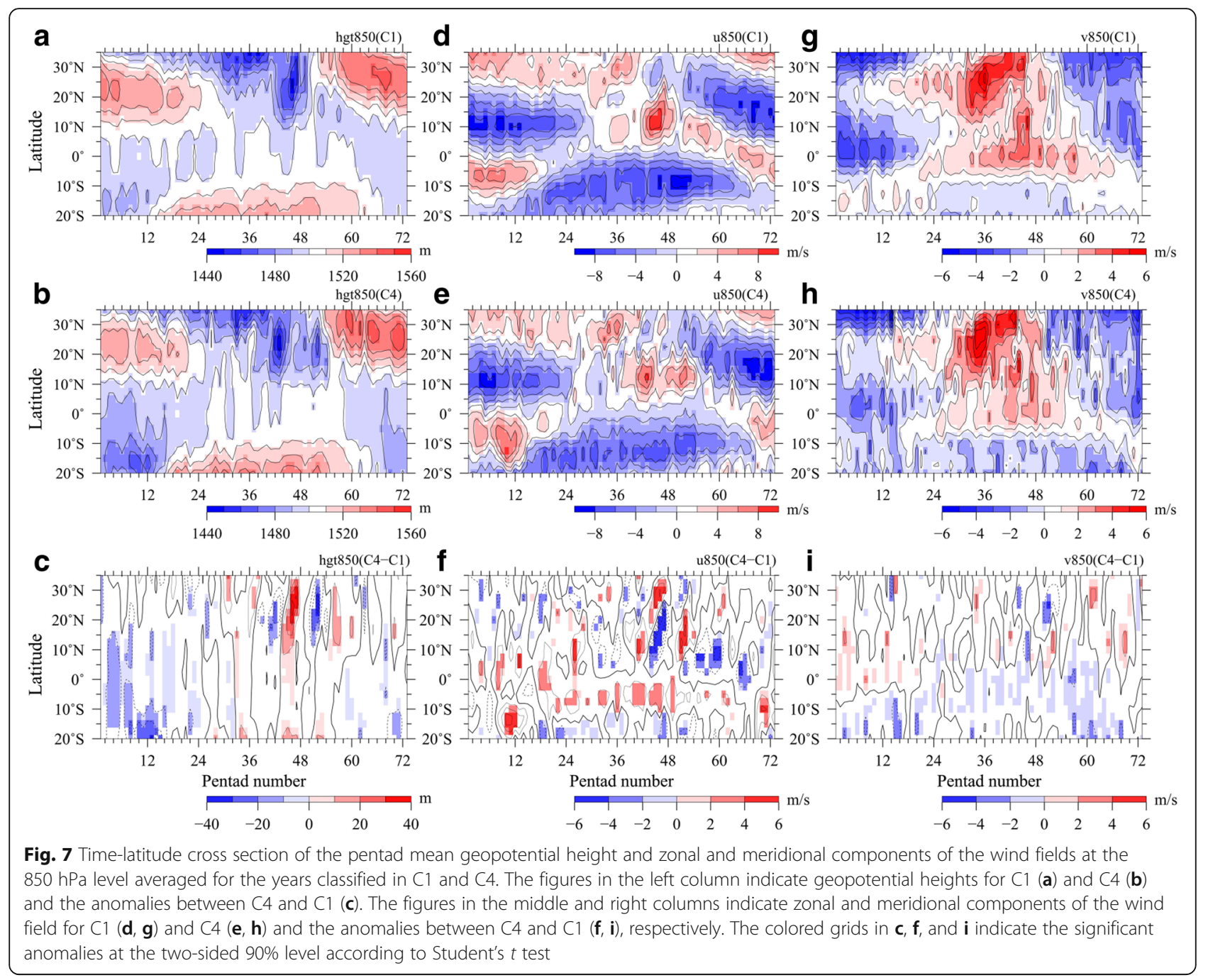

around the Philippines from the 21st to the 47th pentads (mid-April to late August; Fig. 9d). Regarding this, the southerly wind of the meridional component started to blow around the Philippines from the 7th pentad (the beginning of February), earlier than that for $\mathrm{C} 1$ (Fig. 9e, f). The negative anomalies of the meridional wind were observed around $5^{\circ} \mathrm{S}-0^{\circ} \mathrm{N}$ during the 20th-60th pentads (early April to late October; Fig. 9f). Significant positive anomalies of geopotential height were observed around $15^{\circ} \mathrm{N}-30^{\circ} \mathrm{N}$ from the 42 nd to the 48th pentads (late July to late August; Fig. 9b). That is, from the beginning of February to early July, the southeasterly winds related to the strengthened subtropical high continue to blow around the Philippines. In mid-July, the summer rainy season starts with a weakened southwest monsoon around the Philippines. Subsequently, the northerly wind of the meridional component started to blow around the entire Philippines from the 54th to the 60th pentads (late September to late October), slower than that for C1 (Fig. 9e). The onset of the northerly winds led to the withdrawal of the summer rainy season as shown by Akasaka et al. (2007). With such changes in the lower atmospheric circulation, in the year classified as $\mathrm{C6}$, there were a distinct dry season, a delayed onset and withdrawal of the summer rainy season, and indistinct peaks in the summer rainfall amounts.

\section{Relationship between the seasonal march of the summer rainy season and ENSO}

In order to discuss the relationship between the interannual and long-term variability in the seasonal march of the summer rainy season and the lower atmospheric circulation, correlation maps between the geopotential heights and the time coefficients of EOF1 for the years classified in each cluster are shown in Fig. 10. The correlation patterns for $\mathrm{C} 1-\mathrm{C} 3$ have similar characteristics to the correlation map for 1951-2012 shown in Fig. 6a $($ Fig. $10 \mathrm{a}-\mathrm{c})$. However, the area with a higher correlation in C4 is limited only around the Philippines as compared to the correlation maps for the other clusters (Fig. 10d). 


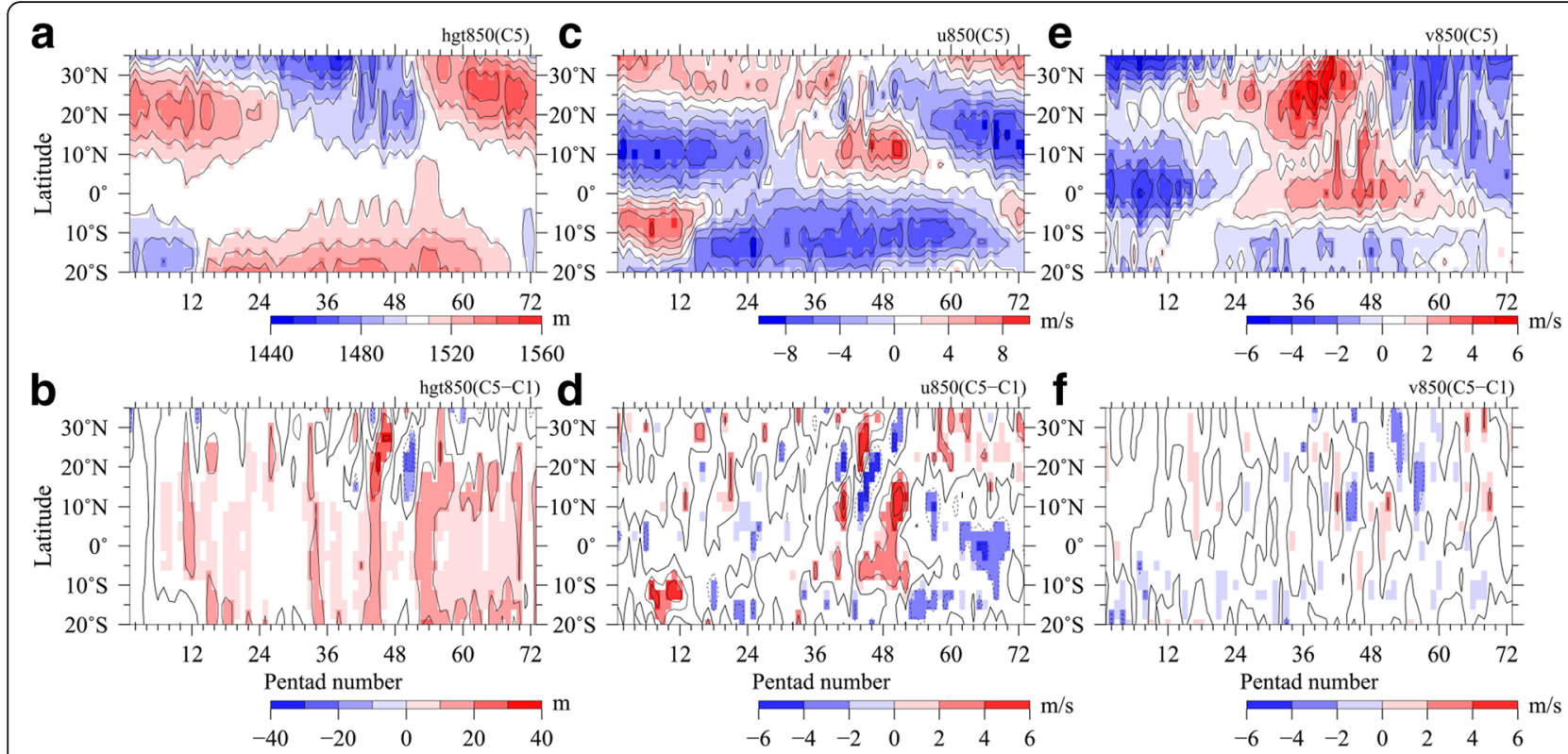

Fig. 8 The same as Fig. 7 except for C5. Figures related to C1 are omitted

Conversely, in the correlation maps for C6, the area with a higher negative correlation mostly appeared from India to the Philippines, and the area with the highest negative correlation coefficient was revealed especially around the Philippines (Fig. 10f). On the other hand, areas with a higher positive correlation were broadly expressed around the tropical eastern Pacific. The east-west contrast of the correlation over the tropical Pacific indicates that C6 is a pattern related to ENSO. The correlation map for C5 revealed a similar pattern to C6, although the positive correlation over the tropical eastern Pacific was lower than that for C6 (Fig. 10e). The correlation patterns between the wind fields and the time coefficients of EOF1 for C5 and C6 also showed such a contrast in correlation (figure not shown). Moreover, Fig. 5b shows that C5 tended to appear in the years when the El Niño condition occurred in JFM and/or OND, except in 1990; C6 tended to appear in the years when the El Niño condition continued from OND in the prior year to the following season (JFM), and La Niña developed for

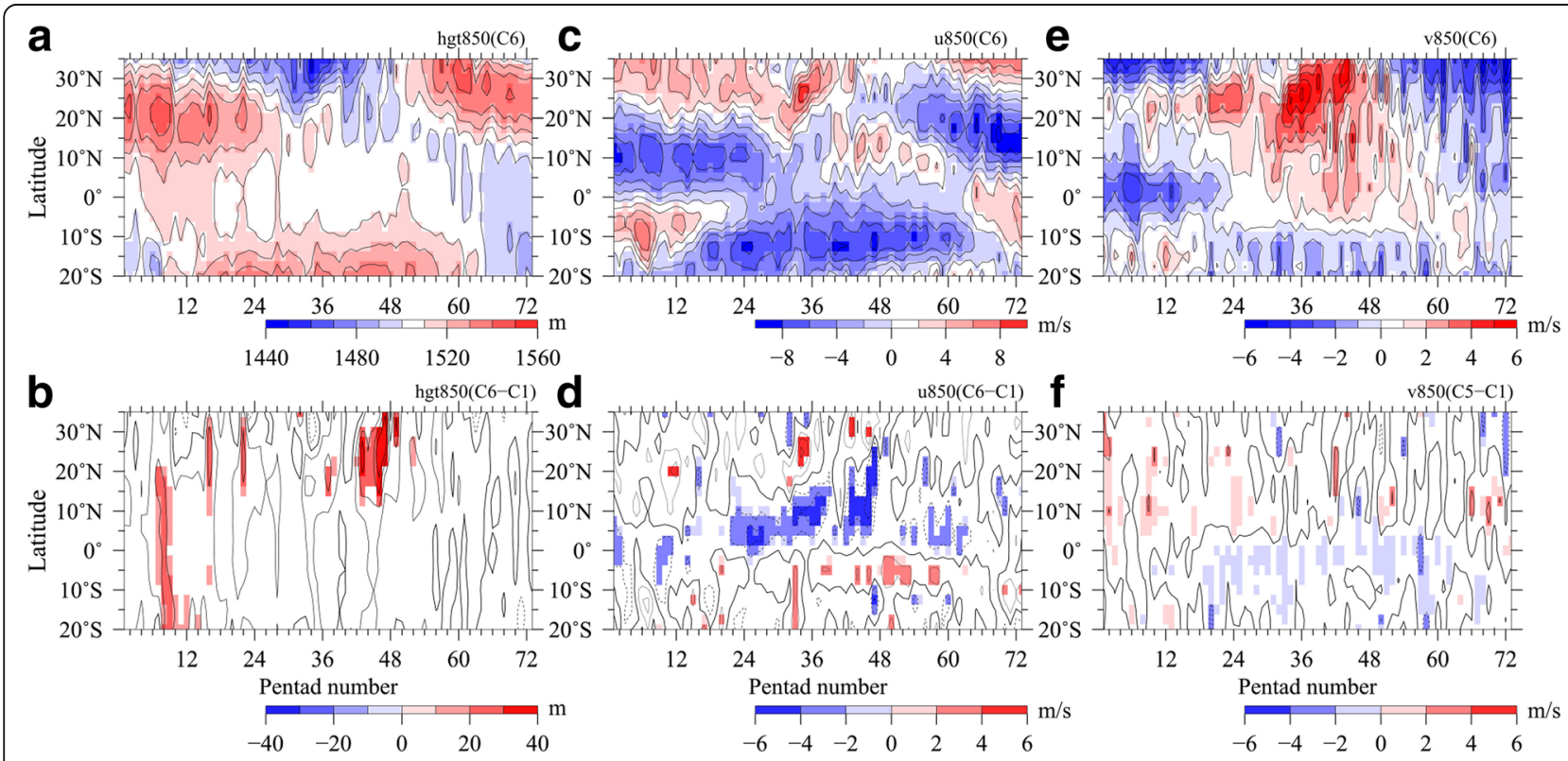

Fig. 9 The same as Fig. 7 except for C6. Figures related to C1 are omitted 


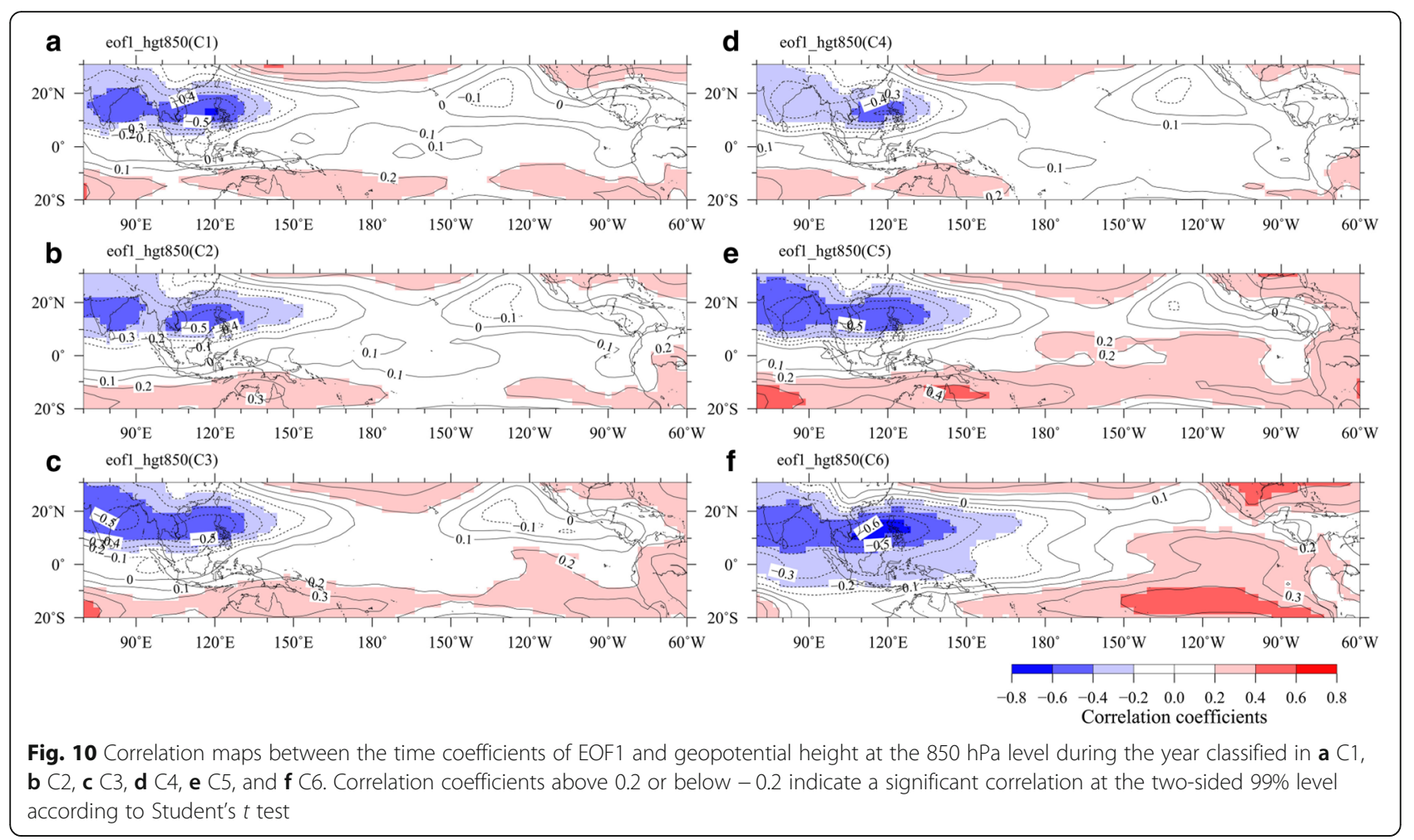

OND, except in 1993. These results suggest that both C5 and C6 are closely related to ENSO.

As pointed out by earlier studies (e.g., Wang et al. 2000; Watanabe and Jin 2002), during the El Niño period and the following season, the Philippine Sea anticyclone developed and suppressed the convective activities over the WNP. Therefore, the seasonal marches of the summer rainy season in C5 and C6 might have revealed similar characteristics as a distinct dry season and the delayed onset of the summer rainy season. On the other hand, C4 had different characteristics as an indistinct dry season and tended to appear in the years when the La Niña condition continued from OND of the prior year to the following season (JFM) or OND of the year (Fig. 5b). Chou et al. (2003) studied the relationship between the interannual variability in the WNP summer monsoon and ENSO and pointed out that the strong WNP summer monsoon tended to occur during an El Niño developing year and a La Niña decaying year. Thus, it is suggested that $\mathrm{C} 4$ is related to changes in the lower atmospheric circulation by La Niña because C4 is observed in the La Niña decaying or continuing year (Fig. 5b). Consequently, it is suggested that ENSO greatly influences the anomalous patterns in seasonal march of rainfall like $\mathrm{C} 4, \mathrm{C} 5$, and C6. It is worth noting, however, that the influences of El Niño and La Niña on the seasonal march patterns of rainfall are not always symmetrical.

Moreover, anomalous patterns in the summer rainy season have frequently been observed especially since the early 1990s. One possible reason is an interdecadal or centennial variability in ENSO shown by some earlier studies. For example, Chung and Tim (2013) studied the interdecadal relationship between the trade wind and SST with the change in El Niño types over the tropical eastern Pacific for the period between 1980 and 2010 . They pointed out that the mean state over the equatorial Pacific showed a regime change to the La Niña-like interdecadal mean state in 1998/1999 with the transition phase of the Pacific Decadal Oscillation (PDO). The point of change is coincident with the year when $\mathrm{C} 4$ started to be frequently observed (Fig. 5b). Additionally, Yim et al. (2008) showed that the interdecadal relationship between the East Asian-WNP summer monsoons and ENSO has changed around 1993/1994. Similarly, Kwon et al. (2005) showed the interdecadal change in the atmospheric circulation and precipitation over East Asia and WNP around the early 1990s. The time when the interdecadal shift in the land-air-sea interactions occurred is coincident with the year when C6 started to appear more frequently (Fig. 5b).

Meanwhile, on the basis of both longer observational and model results of sea surface level over the tropics, Vecchi et al. (2006) pointed out that the Walker circulation weakened from the late nineteenth century to around 2000. Kubota et al. (2017), who studied the influence of tropical cyclones and summer monsoon onset in the Philippines from 1903 to 2013, also pointed out a weak correlation between ENSO and the Philippine 
summer monsoon onset date since around the 1980s. Similarly, Chowdary et al. (2012), who studied interdecadal variations in ENSO teleconnections to the Indowestern Pacific for the period between 1870 and 2007, pointed out that the centennial modulation of ENSO teleconnections to the Indo-northwest Pacific region was correlated not with the PDO but rather with ENSO variance itself. These results by earlier studies suggest that the interdecadal or slower variability in ENSO is associated with the long-term change in the seasonal march pattern of rainfall for the period of 1951-2012. Thus, to clarify its relation with the interdecadal or slower variability in ENSO, it will be essential to study the relationship between the longer term variability in the seasonal march of rainfall and the slower modulation of air-sea interactions over the tropics.

\section{Conclusions}

This study showed the long-term variability in the seasonal march patterns of the summer rainy season in the Philippines from 1951 to 2012 for the first time. On the basis of the EOF analysis of the pentad rainfall, we focused on a dominant pattern in the temporal and spatial structures of rainfall shown by EOF1: a pattern related to the summer rainy season with increases in rainfall from mid-May and decreases in rainfall toward mid-December throughout the Philippines. The patterns obtained from the time coefficients of EOF1 were classified into six clusters by cluster analysis.

The six clusters showed notable long-term variability: three of the six clusters tended to appear more frequently since the early 1990s. Conversely, the normal pattern before 1990 (C1) appeared only in 2007. The three patterns revealed the following characteristics: (1) a pattern which has an indistinct dry season and a prolonged peak rainfall (C4), (2) a pattern which has a distinct dry season and a shortened summer rainy season (C5), and (3) a pattern with a distinct dry season and a delayed onset and withdrawal of the summer rainy season (C6).

In particular, C4 exhibited a significant anomalous pattern, showing an indistinct dry season for January-March. The indistinct dry season was closely related to significantly negative geopotential height anomalies around $15^{\circ} \mathrm{S}-15^{\circ} \mathrm{N}$, especially from January to March. Conversely, C5 and C6 are distinguished by a dry season, and they were correlated to significantly positive geopotential height anomalies for February-March. This means that the duration and condition of the dry season are influenced by the strength and location of the subtropical high around the Philippines especially for February-March (Additional file 1: Figure S11). Moreover, C4 has an earlier onset of the summer rainy season related to an earlier onset of the westerly winds and the prolonged peak rainfall related to the strong westerly winds. Consequently, these changes in the lower atmospheric circulation have led to wetter conditions throughout the years classified in C4. This study suggests that changes in the lower atmospheric circulation that brings wetter conditions have increased in frequency since the late 1990s.

On the other hand, C6 shows drier conditions: there were not only a distinct dry season but also a delayed onset and withdrawal of the summer rainy season and indistinct peak rainfall with small rainfall amounts compared with any other patterns. The delayed onset (withdrawal) of the summer rainy season was closely correlated to the delayed onset of the westerly (northerly) wind in the zonal (meridional) component. This resulted in a shorter duration of the westerly winds. The indistinct peak rainfall was significantly connected to the weakened westerly winds around the Philippines during the summer monsoon. This study also revealed that these changes in the lower atmospheric circulation related to C6 have tended to occur since the early 1990s.

This study suggests that ENSO characterizes the seasonal pattern of the summer rainy season. This is because the correlation maps between the time coefficients of EOF1 and geopotential heights for C5 and C6 showed a pattern related to El Niño: they indicated an east-west contrast in the correlation between the WNP and the equatorial eastern Pacific. Moreover, El Niño tended to occur in JFM and/or OND of the years classified in C5 and C6. Conversely, La Niña tended to continue from OND of the prior year to the following season (JFM) or OND of the year classified in C4. This study showed that these three anomalous patterns in seasonal rainfall have appeared frequently since the early 1990s. This suggests that long-term changes in the seasonal pattern of the summer rainy season are greatly influenced by those in ENSO. To clearly understand the cause of the long-term variability in the seasonality of the summer rainy season, clarification regarding its relation to the interdecadal or slower modulation of ENSO in the near future is necessary.

\section{Additional file}

Additional file 1: Figure S11. Composite anomalies of geopotential height at the $850 \mathrm{hPa}$ level averaged for the 7th-18th pentads (the end of January to the end of March) between C1 and each cluster. (a) Shows a composite map averaged for the 7th-18th pentads of the years classified in C1. (b)-(f) Show composite anomalies between C1 and each cluster. (EPS $4054 \mathrm{~kb}$ )

\section{Abbreviations}

CMAP: Climate Prediction Center Merged Analysis of Precipitation; ENSO: El Niño-Southern Oscillation; EOF: Empirical orthogonal function; ERSST: Extended Reconstructed Sea Surface Temperature; NCEP/NCAR: National Centers for Environmental Prediction/National Center for Atmospheric Research; NOAA: National Oceanic and Atmospheric Administration; ONl: Oceanic Niño Index; PAGASA: Philippine Atmospheric, Geophysical and Astronomical Services 
Administration; PDO: Pacific Decadal Oscillation; PJ: Pacific-Japan; SCS: South China Sea; SST: Sea Surface Temperature; WNP: Western North Pacific

\section{Acknowledgements}

We would like to thank Professor Wataru Morishima, Nihon University for the helpful suggestions. We sincerely thank two anonymous reviewers for the fruitful and constructive comments to our manuscript.

\section{Funding}

This research was supported by the Green Network of Excellence program and the Data Integration and Analysis System through the National Key Technology, Marine Earth Observation Exploration System of Ministry of Education, Culture, Sports, Science and Technology, Japan. This research was also supported in part by the JSPS KAKENHI Grant-in-Aid for Scientific Research of the MEXT 26220202 (Leader: Jun Matsumoto) and 15K16283 (Leader: Ikumi Akasaka). JM was supported by the Tokyo Human Resources Fund of Tokyo Metropolitan University from the Tokyo Metropolitan Government.

\section{Availability of data and materials}

The NCEP/NCAR reanalysis dataset are available from NOAA's Earth System Research Laboratory website; https://www.esrl.noaa.gov/psd/data/reanalysis/ reanalysis.shtml. The ONI data is available from NOAA's Climate Prediction Center website; http://origin.cpc.ncep.noaa.gov/products/analysis_monitoring/ ensostuff/ONI_v4.shtml. The daily rainfall data is available from PAGASA on request.

\section{Authors' contributions}

IA proposed the topic and designed the study. EC, GR, and FH prepared the rainfall data. IA analyzed the data. HK and JM helped in the interpretation of data and collaborated with the corresponding author in the construction of manuscript. All authors read and approved the final manuscript.

\section{Authors' information}

IA is an associate professor at Senshu University. HK is an associate professor at Hokkaido University, and JM is a professor at Tokyo Metropolitan University. EO, GR, and FH are researchers at PAGASA.

\section{Competing interests}

The authors declare that they have no competing interests.

\section{Publisher's Note}

Springer Nature remains neutral with regard to jurisdictional claims in published maps and institutional affiliations.

\section{Author details \\ ${ }^{1}$ Department of Geography, Senshu University, 2-1-1 Higashi-Mita, Tama-ku, Kawasaki, Kanagawa 214-8580, Japan. ${ }^{2}$ Hokkaido University, Kita 10, Nishi 8, Kita-ku, Sapporo, Hokkaido 060-0808, Japan. ${ }^{3}$ Department of Geography, Tokyo Metropolitan University, 1-1 Minami-Osawa, Hachioji, Tokyo 192-0397, Japan. ${ }^{4}$ Department of Coupled Ocean-Atmosphere-Land Processes Research, Japanese Agency for Marine-Earth Science and Technology ". Yokosuka, Kanagawa 237-0061, Japan. ${ }^{5}$ Philippine Atmospheric, Geophysical and Astronomical Services Administration, Science Garden Complex, Diliman, 1101 Quezon City, Philippines.}

\section{Received: 7 July 2017 Accepted: 13 March 2018}

\section{Published online: 26 March 2018}

\section{References}

Akasaka I (2010) Interannual variations in seasonal march of rainfall in the Philippines. Int J Climatol 30:1301-1314. https://doi.org/10.1002/joc.1975.

Akasaka I, Morishima W, Mikami T (2007) Seasonal march and spatial difference of rainfall in the Philippines. Int J Climatol 27:715-725. https://doi.org/10.1002/ joc. 1428

Cayanan EO, Chen T, Argete J, Ten M, Nilo P (2011) The effect of tropical cyclones on southwest monsoon rainfall in the Philippines. J Meteor Soc Jpn 89:123-139. https://doi.org/10.2151/jmsj.2011-A08

Chang CP, Wang Z, Mcbride J, Liu CH (2005) Annual cycle of Southeast Asia-maritime continent rainfall and the asymmetric monsoon transition. J Clim 18:287-301. https://doi.org/10.1175/JCLI-3257.1
Chou C, Tu JY, Yu JY (2003) Interannual variability of the western North Pacific summer monsoon: differences between ENSO and non-ENSO years. J Clim 16:2275-2287. https://doi.org/10.1175/2761.1

Chowdary JS, Xie SP, Tokinaga H, Okumura YM, Kubota H, Johnson N, Zheng XT (2012) Interdecadal variations in ENSO teleconnection to the Indo-western Pacific for 1870-2007. J Clim 25:1722-1744. https://doi.org/10.1175/ JCSI-D-11-0070.1.

Chung PH, Tim L (2013) Interdecadal relationship between the mean state and El Niño types. J Clim 26:361-378. https://doi.org/10.1175/JCLI-D-12-00106.1

Coronas J (1920) The climate and weather of the Philippines, 1903-1918. Manila Observatory, Philippines

Cruz FT, Narisma GT, Villafuerte MQ II, Chua KC, Olaguera LM (2013) A climatological analysis of the southwest monsoon rainfall in the Philippines. Atmos Res 122:609-616. https://doi.org/10.1016/j.atmosres.2012.06.010

Flores JF, Balagot VF (1969) Climate of the Philippines. In: Arakawa H (ed) Climate of northern and eastern Asia, World Survey of Climatology, vol 8. Elsevier, Amsterdam

Huang B, Banzon VF, Freeman E, Lawrimore J, Liu W, Peterson TC, Smith TM, Thorne PW, Woodruff SD, Zhang HM (2015) Extended Reconstructed Sea Surface Temperature version 4 (ERSST.v4): part I. Upgrades and intercomparisons. J Clim 28:911-930. https://doi.org/10.1175/JCLI-D-14-00006.1

Kajikawa Y, Wang B (2012) Interdecadal change of the South China Sea summer monsoon onset. J Clim 25:3207-3218. https://doi.org/10.1175/JCLI-D-11-00207.1

Kalnay E, Kanamitsu M, Kistler R, Collins W, Deaven D, Gandin L, Iredell M, Saha S, White G, Woolen J, Zhu Y, Chelliah M, Ebisuzaki W, Higgins W, Janowiak J, Mo KC, Ropelowski C, Wang J, Leetmaa A, Reynolds R, Jenne R, Joseph D (1996) The NCEP/NCAR 40-year reanalysis project. Bull Am Meteorol Soc 77:437-471

Kubota H, Kosaka Y, Xie SP (2016) A 117-year long index of the Pacific-Japan pattern with application to interdecadal variability. Int J Climato 36:1575-1589. https://doi.org/10.1002/joc.4441

Kubota H, Shirooka R, Matsumoto J, Cayanan EO, Hilario FD (2017) Tropical cyclone influence on the long-term variability of Philippine summer monsoon onset. Progr Earth Planet Sci 4:27. https://doi.org/10.1186/ s40645-017-0138-5

Kubota H, Wang B (2009) How much do tropical cyclones affect seasonal and interannual rainfall variability over the western North Pacific? J Clim 22:5495-5510. https://doi.org/10.1175/2009JCLI2646.1

Kwon MH, Jhun JG, Wang B, An SI, Kug JS (2005) Decadal change in relationship between east Asian and WNP summer monsoons. Geophys Res Lett 32:L16709. https://doi.org/10.1029/2005GL023026

Lyon B, Camargo SJ (2009) The seasonally-varying influence of ENSO on rainfall and tropical cyclone activity in the Philippines. Clim Dyn 32:125-141. https://doi.org/10.1007/s00382-008-0380-z

Lyon B, Cristi H, Verceles ER, Hilario FD, Abastillas R (2006) Seasonal reversal of the ENSO rainfall signal in the Philippines. Geophys Res Lett 33:L24710. https://doi.org/10.1029/2006GL028182

Moron V, Lucero A, Hilario F, Lyon B, Robertson AW, DeWitt D (2009) Spatio-temporal variability and predictability of summer monsoon onset over the Philippines. Clim Dyn 33:1159-1177. https://doi.org/10.1007/s00382-008-0520-5

Ropelewski CF, Halpert MS (1987) Global and regional scale precipitation patterns associated with the El Niño/Southern Oscillation. Mon Wea Rev 115:1606-1626

Tomita T, Yasunari T (1993) On the two types of ENSO. J Met Soc Japan 71:273-284

Vecchi GA, Soden BJ, Wittenberg AT, Held IM, Leetmaa A, Harrison MJ (2006) Weakening of tropical Pacific atmospheric circulation due to anthropogenic forcing. Nature 441:73-76. https://doi.org/10.1038/nature04744

Villafuerte MOII, Matsumoto J, Akasaka I, Takahashi HG, Kubota H, Cinco TA (2014) Long-term trends and variability of rainfall extremes in the Philippines. Atmos Res 137:1-13. https://doi.org/10.1016/j.atmosres.2013.09.021.

Wang B, Wu R, Fu X (2000) Pacific-East Asian teleconnection: how does ENSO affect East Asian climate? J Clim 13:1517-1536

Watanabe M, Jin F (2002) Role of Indian Ocean warming in the development of Philippine Sea anticyclone during ENSO. Geophys Res Lett 29:116.1-116.4. https://doi.org/10.1029/2001GL014318

Wilks DS (2006) Statistical methods in the atmospheric sciences, 2nd edn. Academic Press, Elsevier, Amsterdam

Yim SY, Jhun JG, Yeh SW (2008) Decadal change in the relationship between east Asian-western North Pacific summer monsoons and ENSO in the mid-1990s. Geophys Res Lett 35:L20711. https://doi.org/10.1029/2008GL035751 